\title{
Yield and nutrient content of milk in eight women breast-feeding twins and one woman breast-feeding triplets
}

\author{
BY L. SAINT ${ }^{1}$, P. MAGGIORE ${ }^{2}$ AND P. E. HARTMANN ${ }^{1}$ \\ ${ }^{1}$ Department of Biochemistry, University of Western Australia, Nedlands 6009, \\ Western Australia and ${ }^{2}$ School of Behavioural Science, Division of Health Sciences, \\ Western Australia Institute of Technology, Perth, Western Australia
}

(Received 2 January 1986 - Accepted 23 January 1986)

\begin{abstract}
1. The milk yield of eight mothers each breast-feeding twins was determined by test weighing the mothers. Milk yield was determined at $2,3,6,9$, and 12 months post partum; however, only one mother was studied at all these times.

2. At 6 months post partum the milk yield for individual breasts of three mothers fully breast-feeding and four mothers partially breast-feeding their infants ranged from 0.84 to $2.16 \mathrm{~kg} / 24 \mathrm{~h}$ and 0.42 to $1.39 \mathrm{~kg} / 24 \mathrm{~h}$ respectively. The average frequency of breast-feeding for the mothers studied at 6 months post partum was $15 \cdot 4$ feeds $/ 24 \mathrm{~h}$.

3. The milk yield of one mother fully breast-feeding $2 \cdot 5$-month-old triplets was $3.08 \mathrm{~kg} / 24 \mathrm{~h}$ and the infants were fed twenty-seven times in $24 \mathrm{~h}$.

4. The concentration of lactose, protein and mixed fat in the milk from individual breasts of mothers fully breast-feeding their infants ranged from 65.6 to $82 \cdot 2,7.8$ to 15.7 and 16.7 to $46 \cdot 2 \mathrm{~g} / 1$ respectively. For the three mothers partially breast-feeding 12-month-old infants the values ranged from $54 \cdot 8$ to $71 \cdot 8,14 \cdot 2$ to 19.9 and $4 \cdot 7$ to $40.5 \mathrm{~g} / 1$ respectively.

5. At 6 and 12 months of age, the proportion of the total energy intake of the infants which was derived from breast milk ranged from 64 to $100 \%$ and 6 to $13 \%$ respectively.

6. It is concluded that the maximum potential milk yield for women may be higher than the often quoted value of $700-800 \mathrm{ml} / 24 \mathrm{~h}$.
\end{abstract}

Generally, volumes of breast milk between 700 and $800 \mathrm{ml} / 24 \mathrm{~h}$ have become accepted as the maximum milk yield considered possible from an average healthy and well-nourished mother (Wallgren, 1944 45; Lonnerdahl et al. 1976; Jelliffe \& Jelliffe, 1978 a, $b$; Whitehead, 1983). Further, it has been concluded from these values and from infant growth indices that this milk yield would provide adequate nutrition for the infant for the first 2-3 months of life (Waterlow \& Thompson, 1979; Whitehead et al. 1980; Rowland et al. 1981). Western Australian mothers breast-feeding their infants on demand have been reported to produce greater than $1100 \mathrm{ml} / 24 \mathrm{~h}$ from 2 weeks post partum (Rattigan et al. 1981; Saint et al. 1984). This milk yield would be sufficient to meet the nutritional needs of the infants for more than 8 months (Rowland et al. 1981). Some earlier studies have reported high milk yields and support the Western Australian findings (Macy et al. 1930; Nims et al. 1932; Kaucher et al. 1945; Roderuck et al. 1946). The highest yields were reported by Macy et al. (1930) for women expressing their breast milk for milk banks, in addition to breast-feeding their own infant. These workers concluded that milk yield adjusts to demand and large quantities of breast milk may be produced if the demand is great enough (Macy et al. 1930, 1945; Macy, 1949).

Although studies in animals have shown that the metabolic capacity of the mammary gland increases to meet the nutritional needs of more than one offspring (Hayden et al. 1979; Sadleir, 1980), Deem (1931) is the only available study on milk yield following a multiple birth in women. The study recorded a milk yield of $2355 \mathrm{ml} / 24 \mathrm{~h}$ for one woman breast-feeding twins.

The current study was conducted to determine the yield and composition of breast milk 
Table 1. Details of the mothers studied

\begin{tabular}{|c|c|c|c|c|c|c|c|c|c|}
\hline \multirow[b]{2}{*}{ Mother } & \multirow{2}{*}{$\begin{array}{l}\text { Age of } \\
\text { mother } \\
\text { (years) }\end{array}$} & \multirow{2}{*}{ Delivery } & \multirow[b]{2}{*}{ Gravida } & \multirow[b]{2}{*}{ Parity } & \multirow{2}{*}{$\begin{array}{l}\text { Sex of } \\
\text { infants }\end{array}$} & \multirow{2}{*}{$\begin{array}{c}\text { Preferred } \\
\text { breast }^{*}\end{array}$} & \multicolumn{2}{|c|}{$\begin{array}{c}\text { Maternal } \\
\text { wt (kg) }\end{array}$} & \multirow{2}{*}{$\begin{array}{l}\text { Lactational } \\
\text { amenorrhoea } \\
\text { (months } \\
\text { post partum) }\end{array}$} \\
\hline & & & & & & & Intial & Final & \\
\hline $\mathrm{T}_{1}$ & 26 & $\begin{array}{l}\text { Spontaneous } \\
\text { vaginal }\end{array}$ & 2 & 4 & $\overrightarrow{O A}$ & $R / L$ & $62 \cdot 3$ & $61 \cdot 4$ & 12 \\
\hline $\mathrm{T}_{2}$ & 32 & Caesarian & 2 & 3 & 80 & $\mathrm{R} / \mathrm{L}$ & $74 \cdot 2$ & $74 \cdot 9$ & 12 \\
\hline$T_{3}$ & 27 & Caesarian & 1 & 2 & $\partial^{3} \sigma^{2}$ & $\mathrm{R} / \mathrm{L}$ & $54 \cdot 0$ & $47 \cdot 4$ & 13 \\
\hline $\mathrm{T}_{4}$ & 27 & $\begin{array}{l}\text { Induction } \\
\text { vaginal }\end{array}$ & i & 2 & 웅 & $\mathbf{R} / \mathbf{L}$ & $58 \cdot 2$ & - & 6 \\
\hline$T_{5}$ & 33 & Caesarian & 2 & 3 & 우 & $R / L$ & $51 \cdot 5$ & $55 \cdot 7$ & 13 \\
\hline$T_{6}$ & 30 & Caesarian & 3 & 4 & ofo & $\mathrm{R} / \mathrm{L}$ & $60 \cdot 0$ & $58 \cdot 2$ & 13 \\
\hline $\mathrm{T}_{7}$ & 33 & Caesarian & 1 & 2 & $\sigma^{2} \sigma^{*}$ & $\mathrm{R} / \mathrm{L}$ & $52 \cdot 2$ & $53 \cdot 5$ & 9 \\
\hline $\mathrm{T}_{8}$ & 33 & Caesarian & 1 & 2 & фq & $N / N$ & $80 \cdot 1$ & $77 \cdot 9$ & 9 \\
\hline $\mathrm{Tr}$ & 30 & Caesarian & 2 & 4 & कैं⿰ & $N / N / N$ & $67 \cdot 3$ & - & 7 \\
\hline
\end{tabular}

* $R$, Infant suckled exclusively on the right breast; $L$, infant suckled exclusively on the left breast; $N$, infant suckled at each breast with no preference for right or left breasts.

in eight Western Australian women who gave birth to twins and one woman who gave birth to triplets.

\section{EXPERIMENTAL}

\section{Mothers}

Eight healthy women $\left(\mathrm{T}_{1}-\mathrm{T}_{8}\right)$ who were breast-feeding twins and one woman $(\mathrm{Tr})$ breastfeeding triplets on demand provided informed consent to participate in the study. Details of the mothers are shown in Table 1. Mothers $T_{1}$ and $T_{3}$ were studied at both 6 and 9 months post partum and $T_{2}$ was studied at 6,9 and 12 months post partum. Mother $T_{4}$ was studied at 6 months post partum and $T_{6}$ was studied at 3 and 6 months post partum. Mother $T_{7}$ was studied at $3,6,9$ and 12 months post partum and $T_{5}$ was studied at $2,3,6,9$ and 12 months post partum. Mother $T_{8}$ was only studied at 2 and 3 months post partum.

The pattern of breast-feeding of seven sets of twins was such that each twin only fed from a preferred breast. The infants of mother $T_{8}$ each sucked the right and then the left breasts at each feed. All infants studied at 2 and 3 months of age were fully breast-fed and the infants of mothers $T_{3}, T_{5}$ and $T_{6}$ were fully breast-fed at 6 months of age. Mother $T_{4}$ partially breast-fed her infants (they were suckled at the breast and then offered a supplementary feed of formula from a bottle), whereas all other partially breast-fed infants were supplemented with solids but were not given formula from a bottle. The mother fully breast-feeding triplets (Tr) was studied at 2.5 months post partum. The triplets were fully breast-fed to 4 months post partum and partially breast fed to 4.5 months post partum. This mother normally breast-fed her infants $\left(\operatorname{Tr}_{1}, \operatorname{Tr}_{2}\right.$ and $\left.\operatorname{Tr}_{3}\right)$ in rotation; two infants $\left(\operatorname{Tr}_{1}\right.$ and $\mathrm{Tr}_{2}$ ) were suckled simultaneously on the right and left breast respectively, and the third infant $\left(\mathrm{Tr}_{3}\right)$ suckled both the right and left breasts. At the next feed two infants $\left(\mathrm{Tr}_{2}\right.$ and $\mathrm{Tr}_{3}$ ) were suckled simultaneously at the right and left breasts respectively, and $\operatorname{Tr}_{1}$ was then suckled at both the right and left breast. This step rotation of each infant was recorded by the mother to ensure that each infant was given an equal opportunity at the breast.

\section{Milk yield}

The milk yields of the right breast and left breast respectively, of mothers $T_{1}-T_{8}$ were determined by measuring the decrease in the weight of the mother after each infant was 
suckled at the preferred breast using the method of Rattigan et al. (1981). The mother's weight was recorded with a beam balance (type 3550-AAA balance; Avery Australia Limited) before and after breast-feeding. Mothers performed the test weighings in their home during two separate $24 \mathrm{~h}$ periods at each stage of lactation.

Determination of milk yield from individual breasts was not possible for the mother breast-feeding triplets, since one or other of the three infants fed from both breasts at each feeding period. Therefore, for the measurement of $24 \mathrm{~h}$ milk yield, each infant was breast-fed independently and the mother weighed before breast-feeding and then after each infant had been suckled at the breast.

\section{Milk composition}

Samples of breast milk (about $0.5 \mathrm{ml}$ ) were collected by manual expression from the right and left breasts before (fore sample) and immediately after (hind sample) breast-feeds during the $24 \mathrm{~h}$ periods that the mothers performed the test weighing. Mothers $T_{3}, T_{5}, T_{6}$ and $T_{7}$ collected fore and hind samples from the right and left breasts at each feed for the $24 \mathrm{~h}$ period studied. Mothers $T_{1}, T_{2}, T_{4}, T_{8}$ and $T r$ collected breast milk samples from both breasts at twelve-hourly intervals.

The concentration of lactose in the milk samples was determined as described previously (Hartmann \& Kulski, 1978). The total protein content in the milk samples was determined by a modification of the Lowry assay described by Healy et al. (1980). Total triglyceride concentration of the fore- and hind-milk samples was analysed using a modification of the method of Martin (1975). Estimation of the average concentration of fat in the milk (mixed milk) was calculated using the following equation:

$$
Y=0.61 X_{1}+0.58 X_{2}-0.273,
$$

where $X_{1}$ is the triglyceride concentration in fore milk, $X_{2}$ is the triglyceride concentration in hind milk and $Y$ is the triglyceride concentration in mixed milk (see Hartmann \& Saint,1984).

The energy content of breast milk was calculated by assuming the energy content of milk lactose, protein and fat to be $17 \cdot 4,23.4$ and $39 \mathrm{~kJ} / \mathrm{g}$ respectively (Maynard \& Loosli, 1956).

\section{RESULTS}

\section{Twins}

Milk yield. The milk yields for the right and left breasts for mothers $\mathrm{T}_{5}$ and $\mathrm{T}_{7}$ and mothers $T_{1}, T_{2}, T_{3}, T_{4}, T_{6}$, and $T_{8}$ are shown in Fig. 1 and Table 2 respectively. The milk yield for individual breasts for mothers $T_{5}$ and $T_{7}$ ranged from 0.84 to $1.50 \mathrm{~kg} / 24 \mathrm{~h}$ from 2 to 6 months of lactation and then declined to $0 \cdot 12-0.31 \mathrm{~kg} / 24 \mathrm{~h}$ by 12 months of lactation (Fig. 1). Milk yields for individual breasts for the three mothers who were fully breast-feeding at 6 months of lactation, and for the other four mothers who were partially breast-feeding their infants at this time, ranged from 0.84 to $2 \cdot 16 \mathrm{~kg} / 24 \mathrm{~h}$ and 0.42 to $1.39 \mathrm{~kg} / 24 \mathrm{~h}$ respectively.

Feeding frequency. The frequency of breast-feeding for the right and left breasts of mothers $T_{5}$ and $T_{7}$ and mothers $T_{1}, T_{2}, T_{3}, T_{4}, T_{6}$, and $T_{8}$ are shown in Fig. 1 and Table 2 respectively. Feeding frequency for each breast ranged from 6 to 12 feeds $/ 24 \mathrm{~h}$ for mothers studied during the first 6 months post partum but dropped to $1-3$ feeds $/ 24 \mathrm{~h}$ for the three mothers studied at 12 months post partum. The average feeding frequency for the seven mothers (right plus left breasts) studied at 6 months of lactation was 15.4 feeds $/ 24 \mathrm{~h}$ and their average total milk yield was $2 \cdot 25 \mathrm{~kg} / 24 \mathrm{~h}$. However, there was no relation between feeding frequency and milk yield for mothers at this stage of lactation (Table 2).

Milk composition. The concentrations of lactose, total protein and mixed fat for the right 


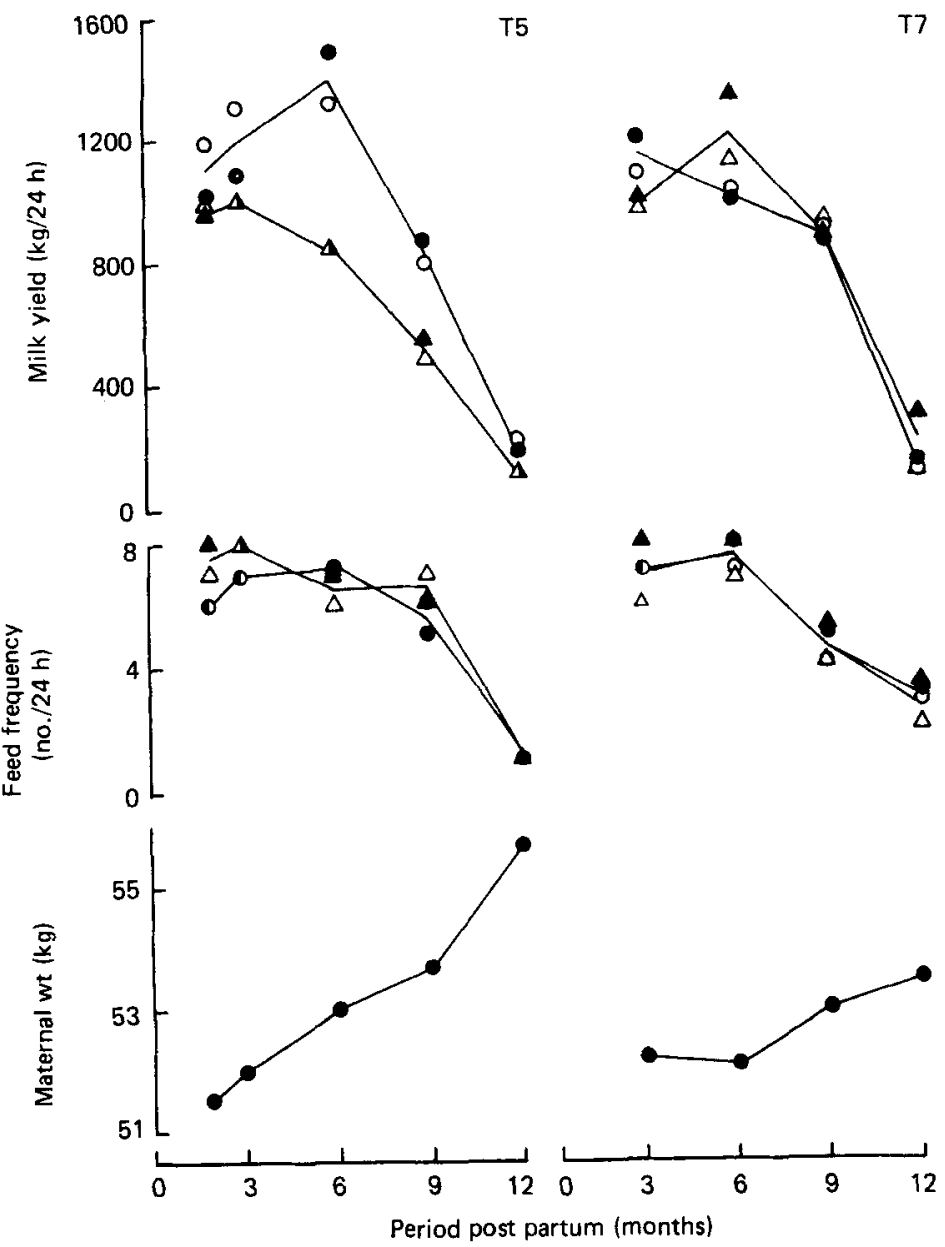

Fig. 1. Progressive changes in the milk yield $(\mathrm{kg} / 24 \mathrm{~h}$ ), frequency of breast-feeding (no. $/ 24 \mathrm{~h}$ ) and body-weight $(\mathrm{kg})$ of mothers $T_{5}$ and $T_{7}$. The milk yield and frequency of breast-feeding was determined for two separate $24 \mathrm{~h}$ periods on the right $(O, O)$ and left $(\Delta, \triangle)$ breast at $2,3,6,9$ and 12 months post partum for $T_{5}$ and at $3,6,9$ and 12 months post partum for $T_{7}$.

and left breasts of the mothers $T_{5}$ and $T_{7}$ and mothers $T_{1}, T_{2}, T_{3}, T_{4}, T_{6}$, and $T_{8}$ are shown in Fig. 2 and Table 2 respectively. The concentration of lactose, protein and mixed fat in milk from individual breasts of mothers fully breast-feeding their infants ranged from 65.6 to $82 \cdot 2,7 \cdot 8$ to $15 \cdot 7$ and $16 \cdot 7$ to $46 \cdot 2 \mathrm{~g} / 1$ respectively. For the three mothers breast-feeding 12-month-old infants the concentration of lactose, protein and mixed fat in milk from individual breasts ranged from 54.8 to $71.8,14.2$ to 19.9 , and 4.7 to $40.5 \mathrm{~g} / 1$ respectively (Fig. 2 and Table 2).

Energy intake from breast milk. The percentage of the energy intake which was derived from breast milk for infants between 6 and 12 months of age is presented in Table 3 . Breast milk was the only source of energy for all infants studied at 2 and 3 months of age and for the infants of mothers $T_{3}, T_{5}$, and $T_{6}$ at 6 months of age. The percentage of the energy intake which was derived from breast milk for the three sets of twins studied at both 6 and 12 months of age declined from 64-100 to 6-13 respectively (Table 3).

Infant weight development. The weight of the infants from birth to 12 months post partum 


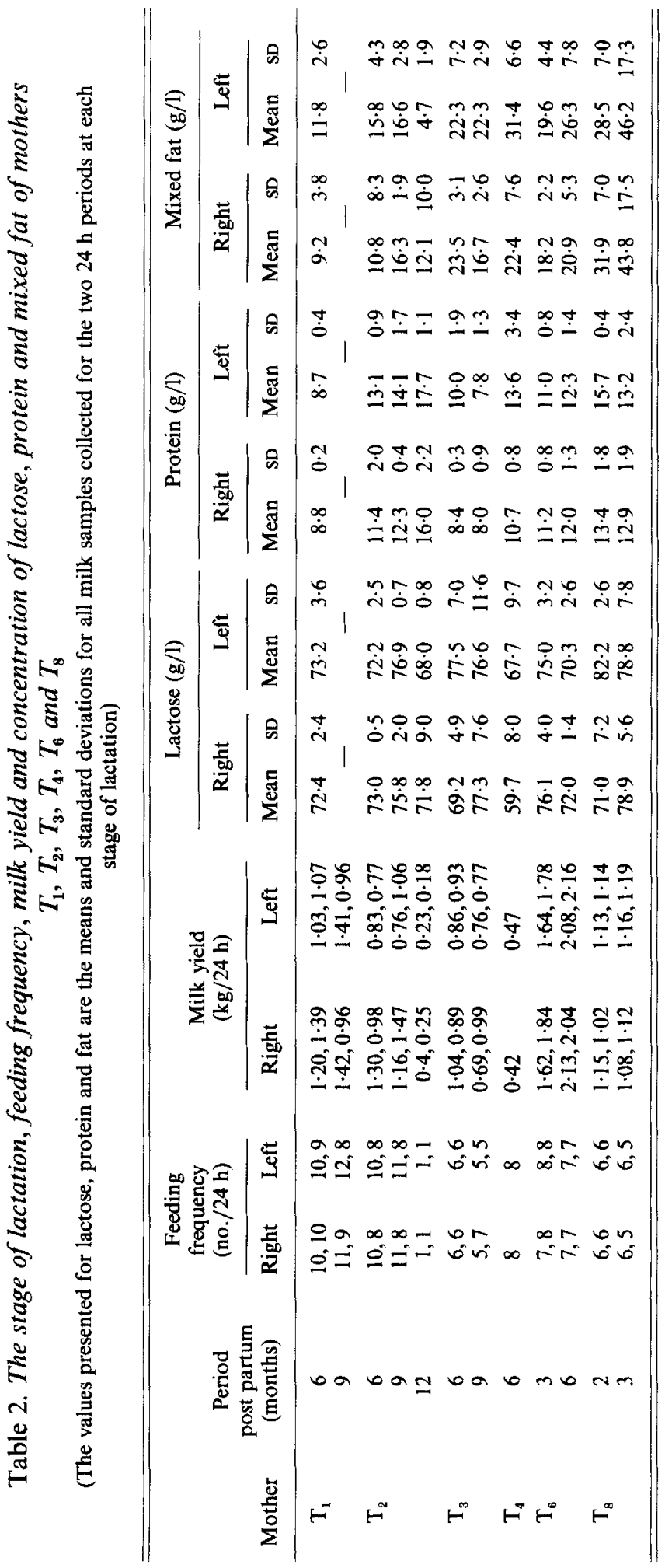



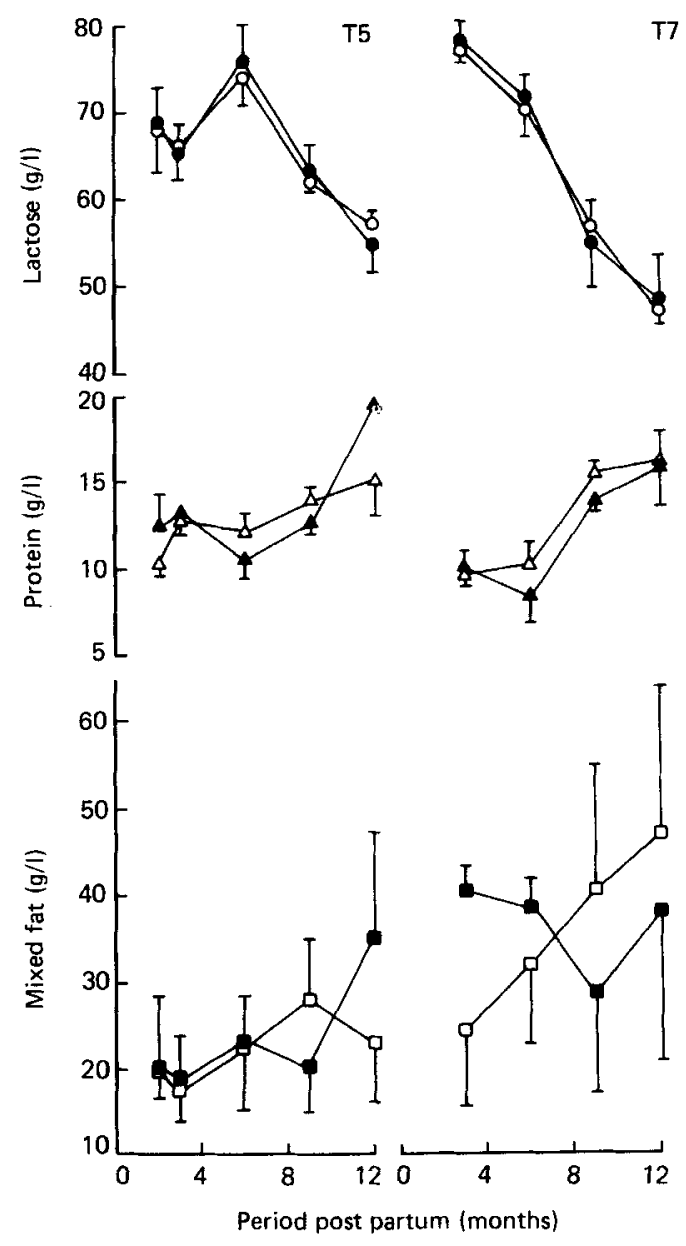

Fig. 2. Changes in the concentrations $(\mathrm{g} / \mathrm{l})$ of lactose, protein and mixed fat for the right $(\mathbf{O}, \mathbf{\Delta}, \mathbf{\square})$ and left $(O, \triangle, \square)$ breasts for mothers $T_{5}$ and $T_{7}$. The values presented are the means and standard deviations, represented by vertical bars, for all milk samples collected for the two $24 \mathrm{~h}$ periods at 2,3 , 6,9 and 12 months post partum for $T_{5}$ and at $3,6,9$ and 12 months post partum for $T_{7}$.

Table 3. The percentage of energy intake derived from breast-milk for infants suckled at the right and left breasts at 6,9 and 12 months post partum

\begin{tabular}{|c|c|c|c|c|c|c|}
\hline \multirow{2}{*}{$\begin{array}{c}\text { Period post } \\
\text { partum (months)... }\end{array}$} & \multicolumn{3}{|c|}{ Right breast } & \multicolumn{3}{|c|}{ Left breast } \\
\hline & 6 & 9 & 12 & 6 & 9 & 12 \\
\hline $\mathrm{T}_{1}$ & 50 & 60 & - & 46 & 59 & - \\
\hline $\mathrm{T}_{2}$ & 66 & 51 & 11 & 61 & 47 & 6 \\
\hline $\mathrm{T}_{3}$ & 100 & 31 & - & 100 & 33 & - \\
\hline $\mathrm{T}_{4}^{3}$ & 43 & - & - & 42 & - & - \\
\hline $\mathrm{T}_{3}$ & 100 & 32 & 13 & 100 & 28 & 9 \\
\hline $\mathrm{T}_{6}$ & 100 & - & - & 100 & - & - \\
\hline $\mathrm{T}_{7}$ & 64 & 52 & 9 & 76 & 60 & 14 \\
\hline
\end{tabular}




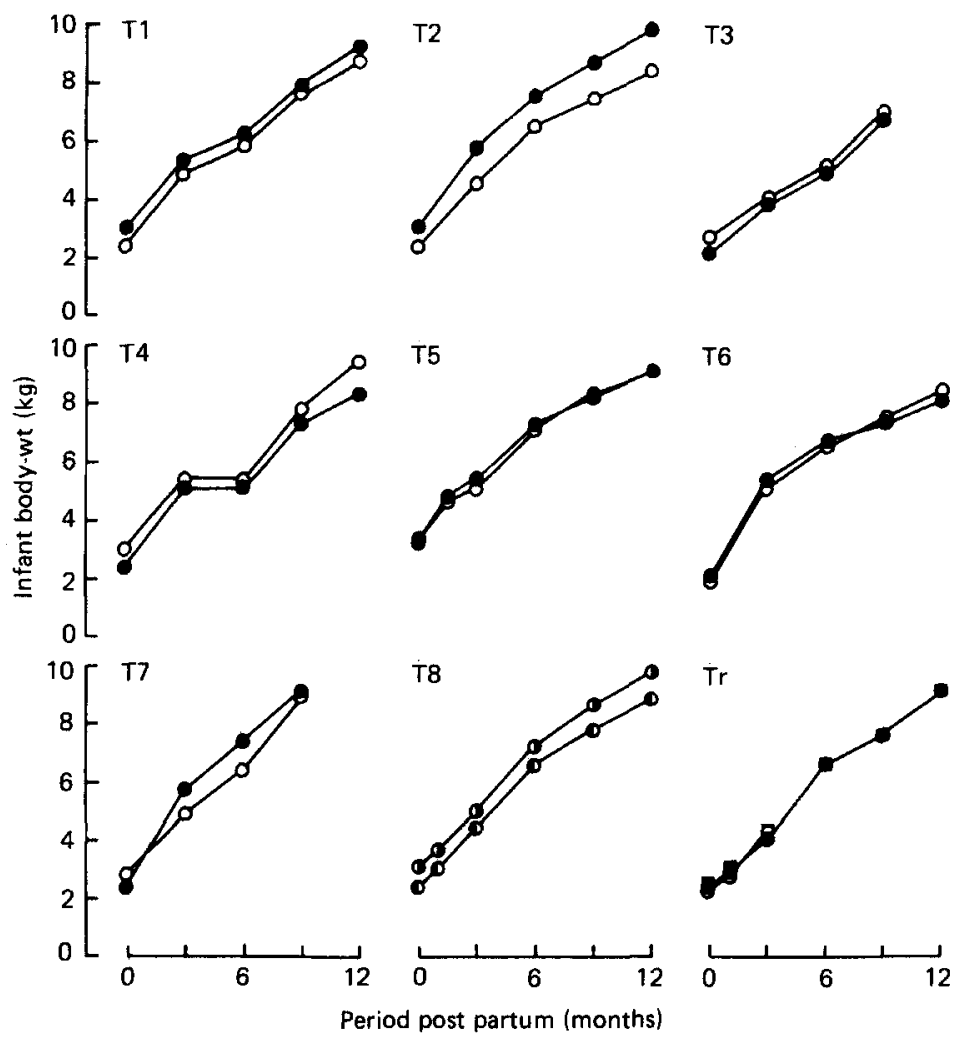

Fig. 3. The nude weight $(\mathrm{kg})$ of the infants suckled exclusively at the right $(O)$ and left $(O)$ breasts respectively, of mothers $T_{1}, T_{2}, T_{3}, T_{4}, T_{5}, T_{6}$, and $T_{7}$, and those of infants $T_{8}$ and $T r$ suckled at either breast, from birth to 12 months of age.

is shown in Fig. 3. The mean birth weights of infants suckled at the right and left breast were 2.75 (SD 0.43) and 2.69 (SD 0.42) kg respectively. All but six of the infants were below the 10th percentile for mass at birth (NH \& MRC, 1975). By 3 months post partum all but four infants were below the 10th percentile for mass. The mean body-weight for the infants fully breast-fed to 6 months of age was 6.36 (SD 0.94$) \mathrm{kg}$, whereas that for infants partially breast-fed at 6 months of age was $6 \cdot 32$ (SD 0.88$) \mathrm{kg}$.

Maternal weight. Maternal weight was recorded on each occasion the mother participated in the study. Weight of each mother at commencement of the study and again at termination of the study are shown in Table 1 and the progressive changes in weight for mothers $T_{5}$ and $T_{7}$ is shown in Fig. 1. Seven mothers participated in the study on more than one occasion and of these women, three $\left(T_{2}, T_{5}\right.$ and $\left.T_{7}\right)$ experienced weight gain during their participation in the study. Four mothers $\left(T_{1}, T_{3}, T_{6}\right.$ and $\left.T_{8}\right)$ experienced an average weight loss of $1 \cdot 15 \mathrm{~kg} /$ month during their lactation.

\section{Triplets}

The volume of breast milk consumed at each feed over a $24 \mathrm{~h}$ period by each of the infants at 2.5 months post partum is shown in Fig. 4. Mother Tr produced a total of $3.08 \mathrm{~kg}$ breast milk and each infant was fed nine times over the $24 \mathrm{~h}$ period. The largest volume of breast milk consumed by each infant occurred between 08.00 and 12.00 hours. The mean concentrations $(\mathrm{g} / \mathrm{l})$ of lactose, total protein and mixed fat in the mother's breast milk were: 


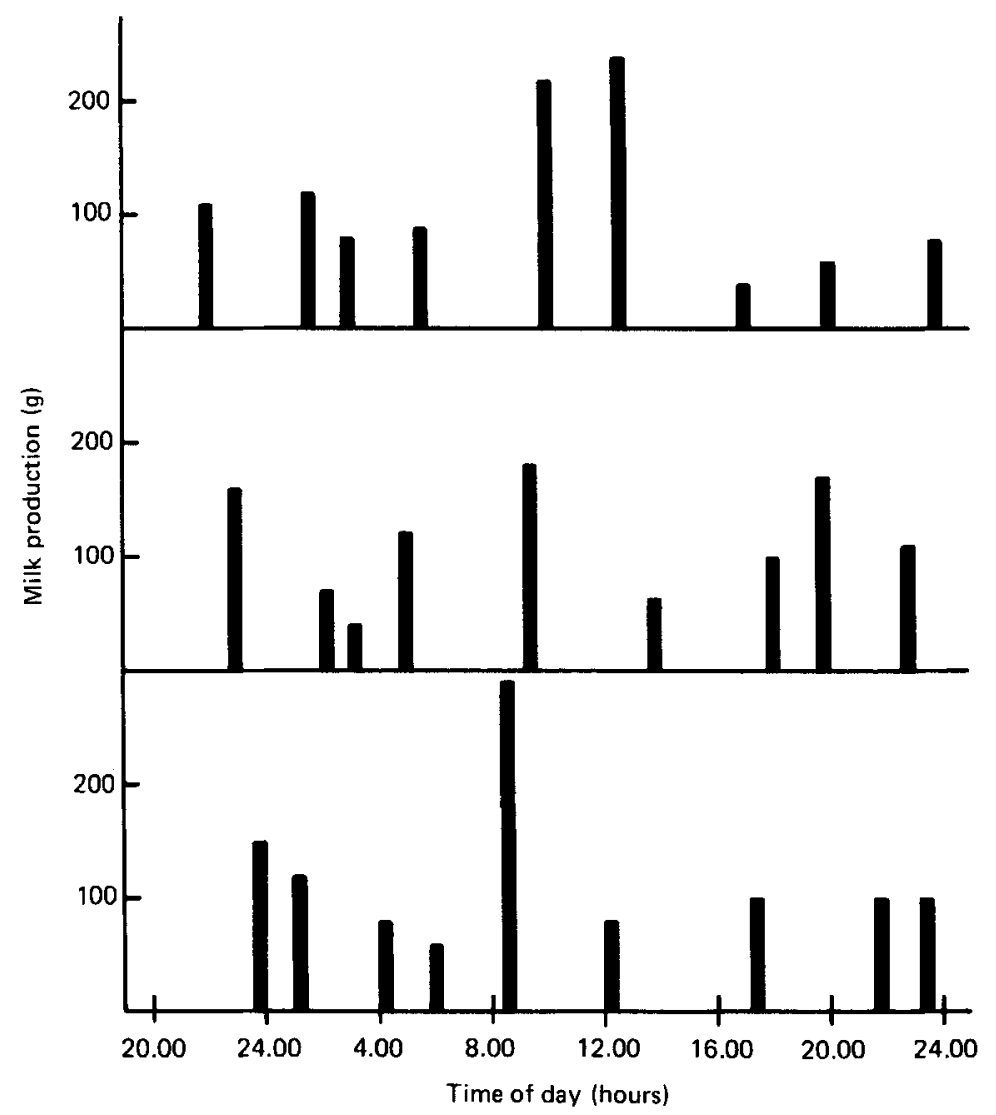

Fig. 4. The intake of breast milk (g) and frequency of breast feeding of triplets $\operatorname{Tr}_{1}, \operatorname{Tr}_{2}$ and $\operatorname{Tr}_{3}$ breast-fed on demand over a $24 \mathrm{~h}$ period at $2 \cdot 5$ months of age.

83.6 (SD 6.7) right breast and 85.1 (SD 7.6) left breast, 9.1 (SD 1.6) right breast and 9.1 (SD

$1 \cdot 2$ ) left breast, $16 \cdot 5$ (SD 6.1) right breast and $15 \cdot 4$ (SD 6.6) left breast respectively.

\section{DISCUSSION}

The number of Western Australian women choosing to breast-feed their infants has increased over the past 10 years (Hartmann et al. 1985) and this has led to an increase in the number of women breast-feeding infants following a multiple birth. Mothers who deliver twins and in some cases triplets are breast-feeding and appear to be successfully meeting the nutritional needs of their infants for several months. Despite obvious difficulties in conducting longitudinal lactation studies with mothers caring for more than one baby, eight mothers breast-feeding twins and one mother breast-feeding triplets were recruited for the study and participated for varying periods during their lactation.

The milk yield of the mothers participating in the study was determined by measuring the decrease in the weight of the mothers at each breast feed over a period of $24 \mathrm{~h}$ with a beam balance (Rattigan et al. 1981). Higher milk yields are obtained using this method compared with test weighing the infant (Saint et al. 1984). This difference is due to sweating and insensible water losses which result in the overestimation of milk yield by about $15 \%$ 
when the mother was test weighed, and the underestimation of milk yield by about $10 \%$ when the infant was test weighed (P. G. Arthur and P. E. Hartmann, unpublished observations). However, it was not possible to correct accurately the present measurements of milk yield because neither the evaporative weight loss of the mothers nor the time-interval between weighings was measured.

Compared with the milk yields reported previously for Western Australian mothers breast-feeding one infant (Rattigan et al. 1981; Saint et al.1984), all but one of the mothers breast-feeding twins produced almost twice as much milk daily when studied during the first 9 months post partum (Table 2 and Fig. 1). It is probable that the increased milk yield in the mothers breast-feeding twins was due to the increased sucking stimulus and milk withdrawal (Table 2 and Fig. 1) rather than the possible promotion of breast growth and development by the twin conceptus during pregnancy. Prosser et al. (1984) observed a mother who was tandem breast-feeding (i.e. the mother breast-fed her infant throughout pregnancy and then breast-fed both the older and the newborn infant after delivery). This mother produced in excess of $2.0 \mathrm{~kg}$ breast milk/d. It was concluded that the additional milk yield resulted from the increase in sucking frequency and milk withdrawal. In this connection, mothers breast-feeding twins on each breast simultaneously were found to have double the prolactin response to sucking compared with mothers breast-feeding one infant (Tyson et al. 1976). However, there is an equivocal relation between the concentration of prolactin in blood and milk yield in women (Cowie et al. 1980).

Deem (1931) reported similar milk yields to those observed in the current study (Table 2 and Fig. 1) for a New Zealand mother breast-feeding twins, as did Prosser et al. (1984) for a mother tandem breast-feeding. Furthermore, Macy et al. (1930) studied three women who breast-fed their babies and expressed surplus milk for a milk bank and found that they produced between 1.5 and 3.0 litres $/ 24 \mathrm{~h}$. In this connection it is of interest that the woman breast-feeding 2.5 -month-old triplets produced approximately $3.0 \mathrm{~kg} / 24 \mathrm{~h}$ and fed twentyseven times in $24 \mathrm{~h}$ (Fig. 4). Together these findings indicate that the maximum potential milk yield for women may be higher than the often quoted value of $700-800 \mathrm{ml} / \mathrm{d}$ (see Whitehead, 1983).

The concentration of lactose in milk samples of the mothers studied (Table 2 and Fig. 2) was generally higher than values previously reported in the literature (Hartmann et al. 1985). In particular, the mother breast-feeding triplets had a mean concentration of lactose in breast milk of 83.6 (SD 6.7) and $85 \cdot 1$ (SD 7.6) g/1 for her right and left breasts respectively. Although a close relation between milk yield and lactose has been reported in both women (Saint et al. 1984) and animals (Hartmann, 1973) during the initiation of lactation, such a relation has not been noted during established lactation.

The energy intake of the twins was similar to values reported by Rattigan et al. (1981) for singletons of a similar age. Although the birth weight of only six of the infants was above $2.8 \mathrm{~kg}$ (the 10th percentile for mass), by 12 months of age there was evidence of 'catch-up' growth and twelve of the infants studied (Fig. 3) had a body-weight greater than $8.5 \mathrm{~kg}$ (the 10th percentile for mass at 12 months post partum). Preliminary studies by Jelliffe (1976) on a group of twins in California fully breast-fed for 3-6 months have shown good rates of growth, indicating that these mothers were adequately meeting the nutritional requirements of their sucking infants. This conclusion has been confirmed by the present study (Fig. 3).

The present findings demonstrate that women are capable of producing enough breast milk to nourish twins. Elucidation of the means by which the mammary gland makes the biochemical adjustments necessary for the mother to meet the nutritional needs of more than one infant is of practical significance, particularly for the poorer mothers in developing nations where adequate milk yield is vital for the survival of their single infants. 
The authors wish to thank the volunteers who participated in the study and the Twins Plus Club of Western Australia for their cooperation. This research was supported by a grant from the NH \& MRC of Australia.

\section{REFERENCES}

Cowie, A. T., Forsyth, I. A. \& Hart, I. C. (1980). Hormonal Control of Lactation. New York: Springer-Verlag. Deem, H. E. (1931). Archives of Diseases in Childhood 6, 53-62.

Hartmann, P. E. (1973). Journal of Endocrinology 59, 231-247.

Hartmann, P. E. \& Kulski, J. K. (1978). Journal of Physiology 275, 1-11.

Hartmann, P. E., Rattigan, S., Saint, L. \& Supriyana, O. (1985). Oxford Reviews of Reproductive Biology 7 , $118-167$.

Hartmann, P. E. \& Saint, L. (1984). Journal of Pediatric Gastroenterology and Nutrition 3, $270-274$.

Hayden, T. J, Thomas, C. R. \& Forsyth, I. A. (1979). Journal of Dairy Science 62, 53.

Healy, D. L., Rattigan, S., Hartmann, P. E., Herington, A. C. \& Burger, H. G. (1980). American Journal of Physiology 238, E83-86.

Jelliffe, D. B. \& Jelliffe, E. F. P. (1978a). Human Milk in the Modern World: Psychological, Nutritional and Economic Significance. Oxford: Oxford University Press.

Jelliffe, D. B. \& Jelliffe, E. F. P. (1978b). Lancet i, 611.

Jelliffe, E. F. P. (1976). In Breast Feeding and the Mother, CIBA Foundation Symposium no. 45. London: CIBA Foundation.

Kaucher, M., Moyer, E. Z., Richards, A. J., Williams H. H., Wertz, A. L. \& Macy, I. G. (1945). American Journal of Diseases in Childhood 70, 142-147.

Lonnerdahl, B., Forsum, E. \& Hambraeus, L. (1976). Nutrition Reports International 13, 125-134.

Macy, I. G. (1949). American Journal of Diseases in Childhood 78, 589-603.

Macy, I. G., Hunscher, H. A., Donelson, E. \& Nims, B. (1930). American Journal of Diseases in Childhood 39, $1186-1204$.

Macy, I. G., Williams, H. H., Pratt, J. P. \& Hamil, B. M. (1945), American Journal of Diseases in Childhood 70, 135-141.

Martin, P. J. (1975). Clinica Chimica Acta 62, 79-88.

Maynard, L. A. \& Loosli, J. K. (1956). Animal Nutrition, 4th ed. York, Pennsylvania: McGraw-Hill.

NH \& MRC (1975). Charts and Tables of Heights, Masses, and Head Circumferences of Infants and Children. Canberra: Australian Government Publishing Service.

Nims, B., Macy, I. G., Hunscher, H. \& Brown, M. (1932). American Journal of Diseases in Childhood 43, 828-844.

Prosser, C. G., Saint, L. \& Hartmann, P. E. (1984). Australian Journal of Experimental Biology and Medical Science 62, 215-228.

Rattigan, S., Ghisalberti, A. V. \& Hartmann, P. E. (1981). British Journal of Nutrition 45, 243-249.

Roderuck, C., Williams, H. H. \& Macy, I. G. (1946). Journal of Nutrition 32, 249-265.

Rowland, M. G. M., Paul, A. A. \& Whitehead, R. G. (1981). British Medical Bulletin 37, 77-82.

Sadleir, R. M. (1980). Journal of Wildlife Management 44, 472-478.

Saint, L., Smith, M. \& Hartmann, P. E. (1984). British Journal of Nutrition 52, 87-95.

Tyson, J.E., Freedman, R. S., Perez, A., Zacur, H. A. \& Zanartu, J. (1976). In Breast Feeding and the Mother, CIBA Foundation Symposium no. 45. London: CIBA Foundation.

Wallgren, A. (1944-45). Acta Paediatrica Scandinavica 32, 778-790.

Waterlow, J. C. \& Thompson, A. M. (1979).Lancet ii, 238-241.

Whitehead, R. G. (1983). Maternal Diet, Breastfeeding Capacity and Lactational Infertility. The United Nations University Food and Nutrition Bulletin, Suppl. 6.

Whitehead, R. G., Paul, A. A. \& Rowland, M. G. M. (1980). Tropical Paediatrics 2, 22-33. 